\title{
Haemoglobin dynamics in Papuan and non-Papuan adults in northeast Papua, Indonesia, with acute, uncomplicated vivax or falciparum malaria
}

Walter RJ Taylor ${ }^{1,2^{*}}$, Hendra Widjaja ${ }^{1}$, Hasan Basri ${ }^{1}$, Emiliana Tjitra ${ }^{3}$, Colin Ohrt ${ }^{4}$, Taufik Taufik ${ }^{5}$, Samuel Baso ${ }^{6}$, Stephen $L$ Hoffman ${ }^{7}$ and Thomas $L$ Richie ${ }^{1}$

\begin{abstract}
Background: Haemoglobin $(\mathrm{Hb})$ recovers slowly in malaria and may be influenced by naturally acquired immunity. $\mathrm{Hb}$ recovery was compared in malaria immune, indigenous Papuan and non-Papuan adults with limited malaria exposure.

Methods: $\mathrm{Hb}$ concentrations were measured on Days (D) 0, 3, 7, and 28 in 57 Papuans and 105 non-Papuans treated with chloroquine, doxycycline or both drugs for acute, uncomplicated Plasmodium vivax $(n=64)$ or Plasmodium falciparum $(\mathrm{n}=98)$.

Results: Mean (SD, range) D0 Hb was $12.7(2.2,7-21.3) \mathrm{g} / \mathrm{dL}$ and was similar in $P$. falciparum infected Papuans and non-Papuans: 12.2 vs. $12.8 \mathrm{~g} / \mathrm{dL}(P=0.15$ ) but significantly lower in: (i) $P$. vivax-infected Papuans vs. $P$. vivax-infected non-Papuans: 11.4 vs. $13.47 \mathrm{~g} / \mathrm{dL}[\Delta=-2.07$ (95\% Cl: $-3.3--0.8), P=0.0018]$, (ii) all patients with splenomegaly (vs. those without splenomegaly): 12.16 vs. $13.01 \mathrm{~g} / \mathrm{dL}[\Delta=-0.85(-1.6--0.085), P=0.029]$, and (iii) all females vs. all males: 10.18 vs. $13.01 \mathrm{~g} / \mathrm{dL}[\Delta=-2.82(-3.97--1.67), P<0.0001]$. Multiple regression identified female sex $(P=0.000)$, longer illness duration ( $P=0.015)$ ( $P$. falciparum patients) and Papuan ethnicity $(P=0.017)(P$. vivax patients) as significant factors for a lower D0 Hb.

Mean D28 Hb increased to $13.6 \mathrm{~g} / \mathrm{dL}[\Delta=1.01(0.5-1.5) \mathrm{vs}$. D0 Hb, $P=0.0001]$. It was: (i) positively correlated with the D0 Hb (adjusted $R^{2}=0.24, P=0.000$ ), and was significantly lower in $P$. vivax infected Papuans vs. non-Papuans: 12.71 vs. $14.46 \mathrm{~g} / \mathrm{dL}[\Delta=-1.7(-2.95--0.5, P=0.006)$.

Conclusions: Haemoglobin recovery was related to baseline Hb. Vivax-infected malaria immune Papuans had persistently lower $\mathrm{Hb}$ concentrations compared to non-Papuans with limited malaria exposure. This haematological disadvantage remains unexplained.
\end{abstract}

Keywords: Anaemia, Malaria, Papuans, Indonesia

\footnotetext{
* Correspondence: bob@tropmedres.ac

${ }^{1}$ The US Navy Medical Research Unit no. 2 (NAMRU-2), Jakarta, Indonesia

${ }^{2}$ Department of Tropical Medicine, Tulane University School of Public Health,

New Orleans, USA

Full list of author information is available at the end of the article
} 


\section{Background}

Malaria-associated anaemia is common and occurs in acute symptomatic infections, severe malaria, chronic asymptomatic infections, and inadequately treated or resistant infections [1-3]. Concomitant hookworm infestation, micronutrient deficiency, inherited blood disorders, and HIV compound the anaemic effects of malaria $[4,5]$.

The main pathophysiological mechanisms in malaria related anaemia are the splenic removal of red cells, bone marrow suppression and dyserythropoesis, and acute haemolytic anaemia (AHA) [1,6]. AHA may occur when parasitized red blood cells (PRBCs) are destroyed by the developing parasite and is potentially greater in Plasmodium falciparum because red blood cells of all ages are invaded and parasitaemia is high. Plasmodium vivax produces a low parasitaemia and invades only reticulocytes [7]. Malaria or drug-induced oxidant stress in patients with glucose-6-phosphate dehydrogenase deficiency may also produce AHA $[8,9]$.

PRBCs and non-parasitized red blood cells (NPRBCs) are removed from the circulation but NPRBCs contribute much more to anaemia and this differs between the species. An estimated 34 NPRBCs in P. vivax [10] and eight NPRBCs in P. falciparum $[2,11]$ are removed from the circulation for one PRBC. The splenic threshold for removing red cells is lowered in falciparum malaria [12] and splenic removal is directly related to spleen size $[1,13]$. Immune related changes to red cells results in their recognition and phagocytosis by activated monocytes and macrophages whilst others are trapped and destroyed in the splenic sinusoids [1,14]. In P. falciparum, NPRBCs and PRBCs have reduced deformability, making splenic trapping easier whilst, because of their increased size, vivax PRBCs have increased deformability but increased fragility, so splenic destruction is more likely [15-17]. The spleen also removes vivax (K. Chotivanich, unpublished data) and falciparum parasites from red cells and returns the deparasitized red cells back to the circulation, a process called pitting [13,18]; pitted RBCs cells also have reduced survival [19].

Depressed bone marrow function and dyserythropoesis result in reduced red cell genesis and reticulocytaemia and poor bone marrow iron utilization is documented in P. falciparum despite adequate bone marrow stores [20]. Bone marrow changes may be related to cytokine imbalances in favour of raised TNF [21,22], the toxic effects of haemozoin [23], a blunted response to erythropoietin [24] and relative under-production of erythropoietin in adults [25].

With effective anti-malarial treatment, the mean haemoglobin $(\mathrm{Hb})$ falls initially, reaching a nadir on Day 3 or Day 7 (most studies have collected data on these days only) and rises thereafter to stabilize at six weeks [2,26-28]. Reticulocytes increase and peak after 1 to 2 weeks [24,29], but the bone marrow may still be abnormal after three weeks $[1,20]$.

Naturally acquired immunity to malaria (NAI) plays a role in limiting malaria-associated anaemia. In African children, the prevalence of anaemia, geometric mean parasite densities, and risk of fever with P. falciparum decrease with increasing age [30,31]. Consistent findings come from northeast Papua where, after approximately two years of intense malaria exposure, malaria naïve non-Papuan adults have similar malariometric indices (malaria prevalence rates, parasite densities, and malaria associated symptoms) as indigenous adult Papuans for $P$. falciparum but not for $P$. vivax. These data suggest the non-Papuan adults had acquired less protective immunity against $P$. vivax compared to $P$. falciparum $[32,33]$.

There is a paucity of data on $\mathrm{Hb}$ dynamics and malaria-associated anaemia from NE Papua. Herein, a post hoc analysis of the $\mathrm{Hb}$ changes between malariaimmune, indigenous Papuans and non-Papuans from other parts of Indonesia with limited malaria exposure is reported.

\section{Methods}

The study took place from October 1995 to January 1998 at the Rumah Sakit Umum (RSU), a public hospital in Jayapura, the capital of Papua Province, Indonesia's most eastern province. Located on the northeast coast of Papua, Jayapura has low rates of malaria transmission but the surrounding lowland area is characterized by intense malaria transmission. Local malariometric data, study conduct and changes in the white blood cell and platelet counts in the same study patients have been detailed elsewhere [34-36]. Briefly, routine haematological parameters $(\mathrm{Hb}$, total white cell and platelet counts) were measured and malaria films taken on Days (D) 0,3 , 7 , and 28 during a trial of patients with acute symptomatic, uncomplicated vivax and falciparum malaria who were treated with either chloroquine $(\mathrm{C})$ alone, chloroquine plus doxycycline (CD), or doxycycline (Dox) alone.

Parasite densities $(\mathrm{N} / \mu \mathrm{L})$ were calculated using the measured total white blood cell counts or assumed to be $8000 / \mu \mathrm{L}$, if the white blood cell count was missing. Double entered and validated data (Epi Info 6.04b, Centers for Disease Control and Prevention, Atlanta, GA, USA) were analysed using Stata v8 (Stata Corporation, USA). Continuous data were compared by ' $t$ ' test or one way ANOVA or the corresponding non-parametric tests, as appropriate. The relationship between two continuous variables was assessed by Pearson's correlation coefficient $(r)$ and coefficient of determination $\left(R^{2}\right)$ for normally distributed data or by Spearman Rho (skewed data). Proportions were compared by Chi-squared test or Fisher's exact test. Backward stepwise multiple regression was performed to assess the independence of 


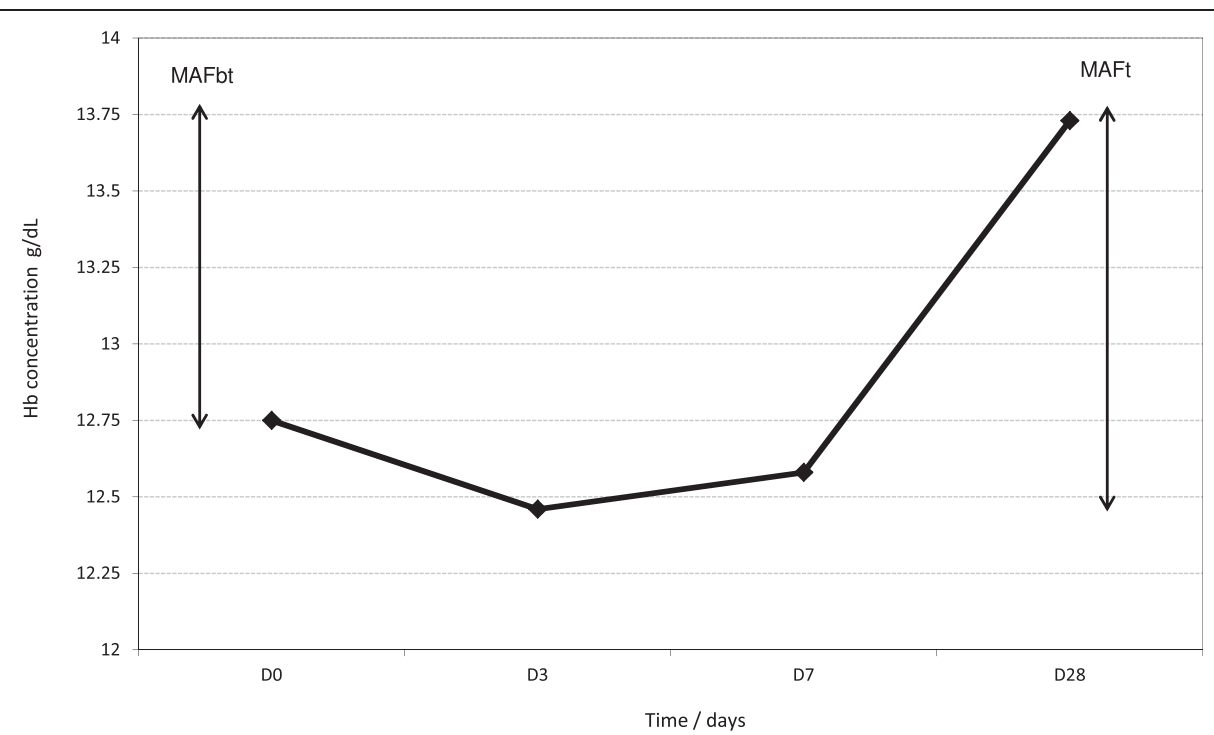

Figure 1 The mean haemoglobin concentrations at Day 0 and during following up, illustrating the total malaria attributable fall in haemoglobin (MAFt) and the malaria attributable haemoglobin fall before treatment (MAFbt).
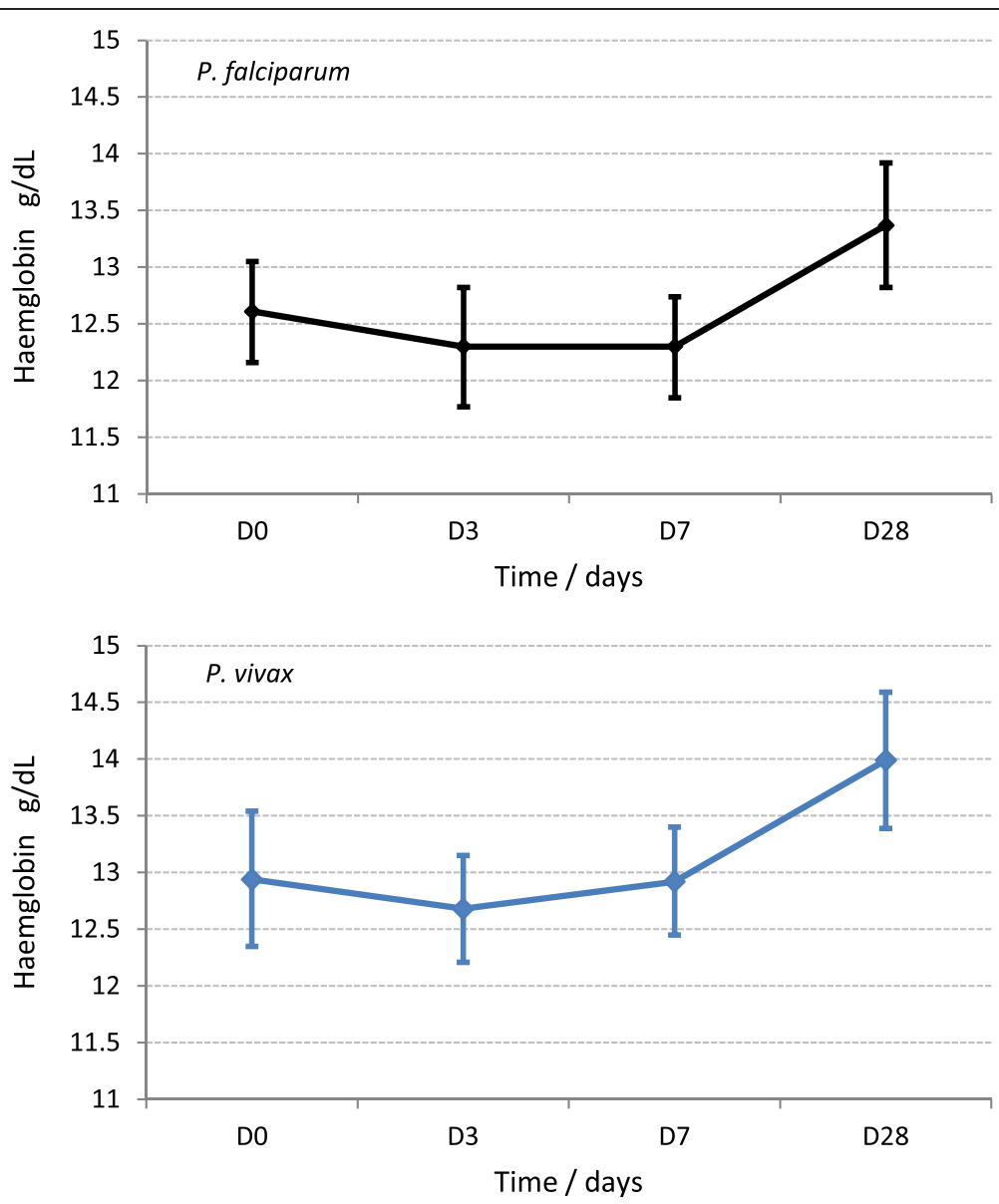

Figure 2 Haemoglobin dynamics for all falciparum and all the vivax-infected patients. 
variables on the $\mathrm{Hb}$ concentrations; adjusted (a) $R^{2}$ values are reported.

Written, informed consent was obtained from all patients. The study was conducted according to the Indonesian Ministry of Health, the Indonesian Navy, the United States Navy and US Army regulations governing the protection of human subjects.

\section{Definitions}

Anaemia of any degree was defined as $\mathrm{Hb}$ concentrations of $<13$ and $<12 \mathrm{~g} / \mathrm{dL}$ in males and females, respectively, and moderate anaemia as $\mathrm{Hb}<11 \mathrm{~g} / \mathrm{dL}$ for both sexes, adapted from the WHO [37].

The mean total malaria attributable fall in Hb following treatment (MAFt) was defined as the difference between the mean D28 $\mathrm{Hb}$ in those successfully treated (i.e. patients without parasites on D28, Hb28wp) and the mean nadir $\mathrm{Hb}$ concentration which, in this study, was Day 3 for both species combined (Figure 1) and for each species (Figure 2). The mean malaria attributable fall in $\mathrm{Hb}$ before treatment (MAFbt) was defined as the mean Hb28wp minus the mean D0 Hb (Figure 1). The relative MAFt (MAFtrel) was expressed as a percentage of the baseline $\mathrm{Hb}$.

\section{Results}

\section{General characteristics}

A total of 162 adult patients (Papuans $=57$, nonPapuans $=105)$ were recruited: Plasmodium vivax $(\mathrm{n}=63)$, P. falciparum $(\mathrm{n}=89)$, and mixed infections $(\mathrm{n}=10)$. These were reclassified as $P$. falciparum $(\mathrm{n}=9)$ and $P$. vivax $(\mathrm{n}=1)$ based on which of the two species had the higher parasitaemia.

Males and females numbered 146 (15-44 years) and 16 (15-33y), respectively. Compared to the non-Papuans, the Papuans had a significantly longer: (i) median residential time, (ii) median time since the preceding episode of clinical malaria, (iii) duration of current illness, (iv) a higher spleen rate (by palpation), (v) a lower median vivax parasitaemia, and (vi) a higher rate of anaemia (Table 1).

\section{Day 0 haemoglobin}

$\mathrm{Hb} 0$ data were available for 152 patients. The mean (SD, range) D0 Hb concentration was $12.7(2.2,7-21.3) \mathrm{g} / \mathrm{dL}$ and was similar between the two species: $P$. vivax 12.9 (2.4) g/dL vs. P. falciparum $12.6(2.1) \mathrm{g} / \mathrm{dL}(P=0.35)$.

Significantly lower mean D0 Hb concentrations (Table 2) were found in: (i) vivax-infected Papuans $v s$. non-Papuans, (ii) all patients with splenomegaly $(\mathrm{n}=47)$ : $12.16 \mathrm{vs}$. $13.01 \mathrm{~g} / \mathrm{dL}$ (without splenomegaly, $\mathrm{n}=105$ ): $\Delta=-0.85$ (-1.6 - -0.085), $P=0.029$, and (iii) all females $(\mathrm{n}=$ 14) 10.18 vs. $13.01 \mathrm{~g} / \mathrm{dL}$ (males, $\mathrm{n}=138$ ): $[\Delta=-2.82$ $(-3.97--1.67), P<0.0001$.

There was a weak negative relationship between illness duration and $\mathrm{D} 0 \mathrm{Hb} \quad\left(\mathrm{R}^{2}=0.04\right)$ and no correlation between the $\mathrm{D} 0 \mathrm{Hb}$ and parasitaemias of both species $(P=0.77, P=0.54)$. Multiple regression of the falciparuminfected patients identified female sex $(P=0.000)$ and illness duration $(P=0.015)$ as significant factors for a lower

Table 1 Demographic, clinical and laboratory characteristics of the Papuan and non-Papuan study subjects at disease presentation

\begin{tabular}{|c|c|c|c|}
\hline & $\begin{array}{l}\text { Papuans } \\
\mathrm{n}=57\end{array}$ & $\begin{array}{l}\text { Non Papuans } \\
n=105\end{array}$ & $\mathbf{P}$ \\
\hline Age & $22(15-39)$ & $24(15-44)$ & 0.0028 \\
\hline Male: Female & $48: 9$ & $98: 7$ & 0.063 \\
\hline Residence in years & $21.5(15-39)$ y & $3(2 m$ to 24$) y$ & 0.000 \\
\hline Previous clinical malaria ${ }^{*+}$ & $2(0-16)$ & $3(0-11)$ & 0.15 \\
\hline Time since last malaria attack & $14 w(8 w-17 m)$ & $9 w(6 w-5.6 m)$ & 0.043 \\
\hline Duration of illness in days ${ }^{\dagger}$ & $4(1-30)$ & $2(1-30)$ & 0.0003 \\
\hline Temperature $^{\dagger}$ & $38(36.5-41)$ & $38.6(36.1-41.3)$ & 0.1 \\
\hline Splenomegaly & $26(45.6 \%)$ & $27(25.7 \%)$ & 0.01 \\
\hline Anaemia $^{\S}$ & $34 / 52(65.4 \%)$ & $36 / 100(36 \%)$ & 0.001 \\
\hline Moderate anaemial & $16 / 52(30.8 \%)$ & $20 / 100(20 \%)$ & 0.138 \\
\hline P. falciparum parasitaemia ${ }^{\ddagger}$ & $3,007(20-64,998)$ & $2,346(38-74,432)$ & 0.76 \\
\hline P. vivax parasitaemia ${ }^{\ddagger}$ & $703(55-9920)$ & $2,592(54-14124)$ & 0.034 \\
\hline
\end{tabular}

Continuous data are median (range) unless otherwise stated.

* number of previous malaria episodes by history.

${ }^{\dagger}$ median (range).

$\S$ Anaemia = haemoglobin $<13 \mathrm{~g} / \mathrm{dL}$ (male), \& $12 \mathrm{~g} / \mathrm{dL}$ (female).

'Moderate anaemia = haemoglobin $<11 \mathrm{~g} / \mathrm{dL}$ both sexes.

‡ median (range). 
Table 2 Mean haemoglobin (standard deviation) and mean haemoglobin changes at follow up in Papuan and non-Papuan adults following treatment for Plasmodium vivax or $P$. falciparum malaria

\begin{tabular}{|c|c|c|c|c|c|}
\hline & Papuans & $\mathbf{N}$ & Non Papuans & $\mathrm{N}$ & $\mathbf{P}$ \\
\hline \multicolumn{6}{|l|}{ Day 0} \\
\hline $\mathrm{Hb}$ & $11.85(1.88)$ & 57 & $13.5(2.27)$ & 105 & 0.009 \\
\hline Males & $12.27(0.26)$ & 44 & $13.35(0.22)$ & 94 & 0.005 \\
\hline Hb falciparum & $12.16(1.97)$ & 36 & $12.94(2.18)$ & 53 & 0.1 \\
\hline $\mathrm{Hb}$ vivax & $11.4(1.59)$ & 16 & $13.47(2.35)$ & 47 & 0.001 \\
\hline \multicolumn{6}{|l|}{ Day 3} \\
\hline $\mathrm{Hb}$ & $11.93(2.02)$ & 46 & $12.86(1.73)$ & 90 & 0.006 \\
\hline Hb falciparum & $12.14(2.12)$ & 31 & $12.65(1.83)$ & 47 & 0.26 \\
\hline $\mathrm{Hb}$ vivax & $11.5(1.78)$ & 15 & $13.09(1.61)$ & 43 & 0.0024 \\
\hline$\triangle \mathrm{Hb} 3 \mathrm{HbO}$ & $-0.03(-0.31$ to +0.24$)$ & 46 & $-0.27(-0.63$ to +0.09$)$ & 90 & 0.39 \\
\hline$\triangle \mathrm{Hb} 3 \mathrm{Hb} 0$ falciparum & $-0.11(-0.48$ to +0.25$)$ & 31 & $-0.17(-0.6$ to +0.26$)$ & 47 & 0.85 \\
\hline$\triangle \mathrm{Hb} 3 \mathrm{Hb} 0$ vivax & $0.12(-0.28$ to +0.53$)$ & 15 & $-0.38(-0.99$ to +0.29$)$ & 43 & 0.33 \\
\hline \multicolumn{6}{|l|}{ Day 7} \\
\hline $\mathrm{Hb}$ & $12.2(1.95)$ & 43 & $12.8(1.76)$ & 83 & 0.1 \\
\hline Hb falciparum & $12.28(2.07)$ & 29 & $12.3(1.71)$ & 40 & 0.96 \\
\hline Hb vivax & $12.06(1.75)$ & 14 & $13.21(1.71)$ & 43 & 0.035 \\
\hline$\triangle \mathrm{Hb} 7 \mathrm{HbO}$ & $0.31(-0.05$ to +0.68$)$ & 42 & $-0.23(-0.71$ to +0.12$)$ & 83 & 0.059 \\
\hline$\triangle \mathrm{Hb} 7 \mathrm{Hb}$ 0 falciparum & $0.17(-0.28$ to +0.64$)$ & 28 & $-0.44(-0.09$ to +0.96$)$ & 40 & 0.09 \\
\hline$\triangle \mathrm{Hb} 7 \mathrm{Hb} 0$ vivax & $0.56(-0.07$ to +1.26$)$ & 14 & $-0.17(-0.49$ to +0.82$)$ & 43 & 0.2 \\
\hline \multicolumn{6}{|l|}{ Day 28} \\
\hline $\mathrm{Hb}$ & $13.07(2.03)$ & 27 & $13.9(1.49)$ & 47 & 0.038 \\
\hline Hb falciparum & $13.23(2.15)$ & 19 & $13.49(1.54)$ & 25 & 0.64 \\
\hline $\mathrm{Hb}$ vivax & $12.71(1.79)$ & 8 & $14.46(1.28)$ & 22 & 0.006 \\
\hline$\triangle \mathrm{Hb} 28 \mathrm{Hb} 0$ & 1.15 (0.55 to 1.76$)$ & 26 & 0.94 (0.25 to 1.63$)$ & 47 & 0.66 \\
\hline$\triangle \mathrm{Hb} 28 \mathrm{Hb} 0$ falciparum & $1.06(0.23$ to 1.9$)$ & 18 & $1.2(0.3$ to 2.1$)$ & 25 & 0.82 \\
\hline$\triangle \mathrm{Hb} 28 \mathrm{Hb} 0$ vivax & 1.36 (0.46 to 2.26$)$ & 8 & $0.64(-0.48$ to 1.75$)$ & 22 & 0.44 \\
\hline
\end{tabular}

D0 $\mathrm{Hb}$. In the vivax-infected patients, being Papuan $(P=0.017)$ was the only significant variable; it was also associated with a lower D0 Hb.

\section{Haemoglobin dynamics}

For all patients combined, the mean $\mathrm{Hb}$ concentration fell to nadir on Day 3: $-0.19(-9.4-4.2) \mathrm{g} / \mathrm{dL}[\equiv-0.55$ $(-44.1-44.7) \%]$; this fall was inversely related to baseline $\mathrm{Hb}(P=0.000$, Additional file 1$)$. By contrast, patients with baseline moderate anaemia had an initial rise on mean $\mathrm{Hb}(0.58(-1.2-4.2) \mathrm{g} / \mathrm{dL}$ on $\mathrm{D} 3)$ that was sustained to D28 (Figure 3).

For all patients combined, $\mathrm{Hb}$ dynamics were similar between the species (Figure 2), the falciparum infected Papuans (Figure 4), and the three drug arms (Additional file 2). The vivax-infected Papuans had a small mean rise in $\mathrm{Hb}$ by D3 (not significantly different to the small increase in the non-Papuans, $P=0.33$ ) but had significantly lower mean $\mathrm{Hb}$ concentrations on D3-28 compared to the non-Papuans with P. vivax (Table 2 and Figure 5).

By $\mathrm{D} 28$, the mean $\mathrm{Hb}(\mathrm{n}=74$ patients) had risen significantly $(P=0.0001)$ to $13.6 \mathrm{~g} / \mathrm{dL}$ and there was a corresponding fall $(P<0.001)$ in the proportion of anaemic patients to $29.73 \%$ (22/74) vs. baseline. The D28 Hb concentration was best explained by the D0 $\mathrm{Hb}$ concentration and sex (multiple regression): $\mathrm{aR}^{2}=0.32(P=0.001)$; removing sex from the model resulted in an $\mathrm{aR}^{2}=0.24$ for $\mathrm{D} 0 \mathrm{Hb}$.

\section{Malaria attributable fall in haemoglobin}

On Day 28, there were 65 patients who were parasite negative and had paired $\mathrm{Hb} 3$ and $\mathrm{Hb} 28$ data; their mean D28 Hb was 13.74 (SD 1.7, range 9.9-18.1) g/dL. The mean (range) MAFt and MAFtrel values were 1.41 $(-1$ - 5.6) g/dL and $12.3(-8.5$ - 62) \%, respectively. The mean MAFbt was 1.07 (-7.9 -6.2) g/dL, representing 


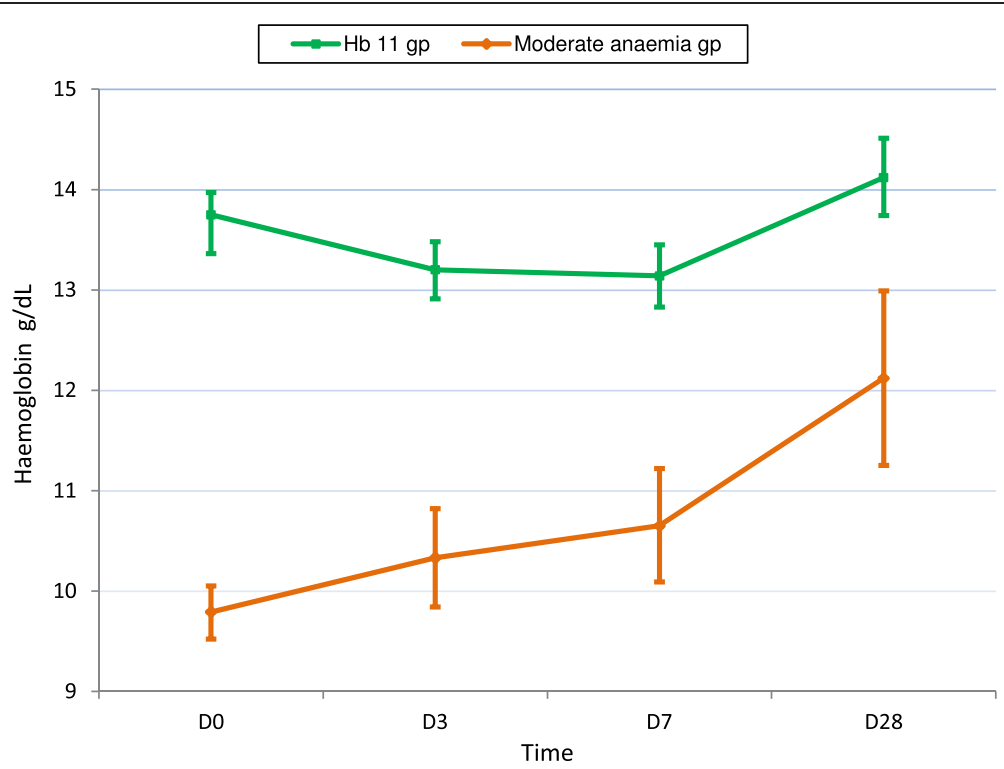

Figure 3 Haemoglobin dynamics for all patients combined as a function of baseline moderate anaemia (Hb $<11 \mathrm{~g} / \mathrm{dL})$.

$75.8 \%(1.07 / 1.41)$ of the MAFt. MAFt and MAFtrel gave essentially the same results in all analyses so MAFtrel results are reported hereafter.

In bivariate analyses, MAFtrel was significantly: (i) negatively correlated with the D0 Hb (Pearson's coefficient $=-2.8, P=0.0001$ ), (ii) positively correlated with illness duration $(P=0.0005)$, (iii) higher $(P=0.0005)$ in patients with D0 moderate anaemia $(\mathrm{n}=16)$ vs. those without moderate anaemia $(\mathrm{n}=49): 23.3 \%$ vs. $6.6 \%$ (these \%s correspond to MAFt concentrations of 1.9 vs. $0.9 \mathrm{~g} / \mathrm{L}$, (iv) higher $(P=0.0067)$ in patients with splenomegaly $(\mathrm{n}=24) v s$. those without splenomegaly $(\mathrm{n}=41): 18.2 \% v s$. 8.8\% (MAFt concentrations of 2.03 vs. $1.05 \mathrm{~g} / \mathrm{L}$ ).

Non-significant MAFtrel factors included: (i) ethnicity: Papuan $10.9 \%$ vs. non-Papuan $13.1 \%(P=0.53)$, (ii) drug treatment $(P=0.53): 7.3 \%(C)$ vs. $12.6 \%(\mathrm{CD})$ vs. $13.7 \%$ (Dox), and sex $(P=0.36): 16.8 \%$ (female) vs. $11.7 \%$ (male).

Multivariate analysis in the falciparum infected patients $\left(\mathrm{aR}^{2}=0.47\right)$, identified four significant variables: Papuan ethnicity and D0 $\mathrm{Hb}$ were inversely correlated whilst illness duration and splenomegaly were positively correlated (Table 3 ). There were no explanatory variables in vivax patients $\left(\mathrm{aR}^{2}=0\right)$.

\section{Discussion}

This study has shown that, for all patients and when stratified by infecting species, haematological recovery was characterized by an initial fall in the mean $\mathrm{Hb}$, followed by a rise, consistent with previous studies of falciparum and vivax malaria [2,38]. By contrast, patients

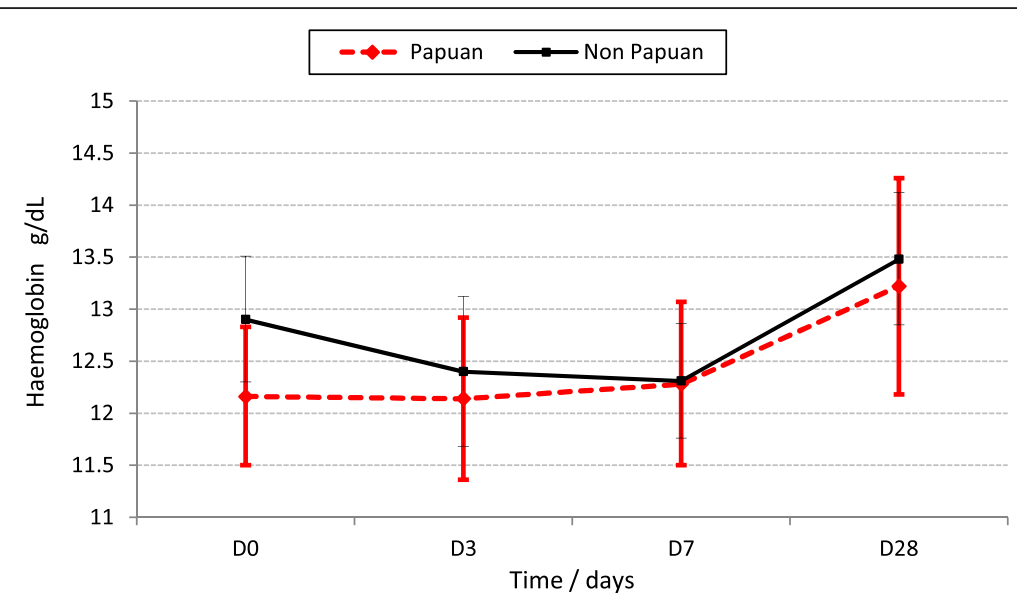

Figure 4 Haemoglobin dynamics in the falciparum infected Papuans and non-Papuans. 


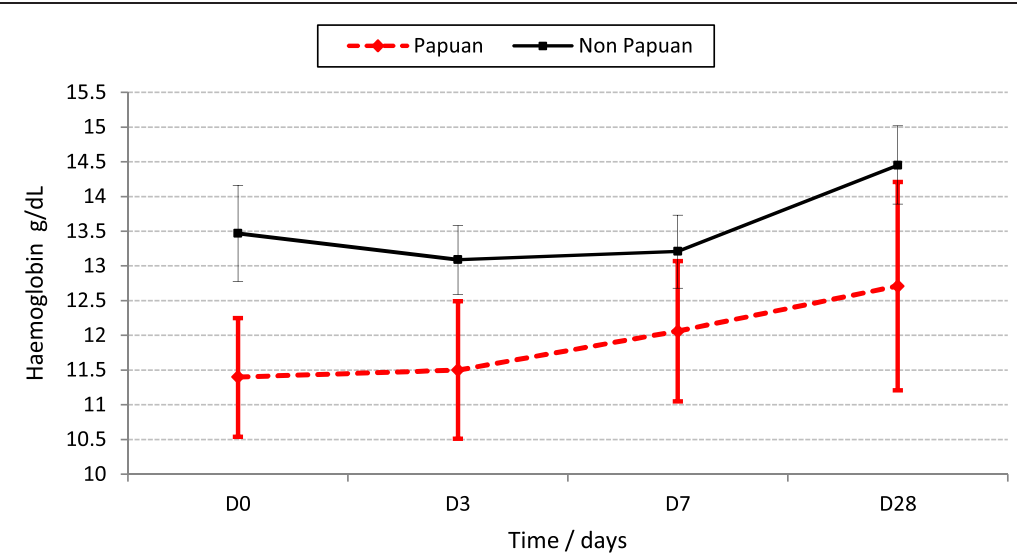

Figure 5 Haemoglobin dynamics in the vivax-infected Papuans and non-Papuans. The mean haemoglobin concentrations were significantly lower in the Papuans at each time point $(P \leq 0.035)$, despite overlapping 95\% confidence intervals.

with moderate anaemia had an initial rise in mean $\mathrm{Hb}$, suggesting they had longer illness durations, had reached their nadir $\mathrm{Hb}$ at presentation and were "primed" to respond to anti-malarial treatment.

For all patients, the initial fall in mean $\mathrm{Hb}$ was modest, $\sim 0.2 \mathrm{~g} / \mathrm{dL}(\sim 0.5 \% v s$. D0 Hb), and was inversely related to the baseline $\mathrm{Hb}$. The subsequent increase in mean $\mathrm{Hb}$, measured by the MAFt, was $1.4 \mathrm{~g} / \mathrm{dL}$; this figure compares favourably to the $\sim 1.2 \mathrm{~g} / \mathrm{dL}$ and $\sim 1.1 \mathrm{~g} / \mathrm{dL}$ in falciparum-infected patients of all ages from western Thailand [2] and Laotian adults [28], respectively, whose follow up was longer (42 days).

The MAFtrel was used in these analyses as it might be better than the MAFt as marker of Hb recovery because it takes into account the baseline $\mathrm{Hb}$. No independent factors were identified to explain the MAFtrel in the vivax patients, suggesting inadequate patient numbers. For the falciparum patients, a higher MAFtrel was associated with a lower $\mathrm{D} 0 \mathrm{Hb}$, a longer illness duration and splenomegaly whereas a lower MAFtrel was associated with being Papuan; these four factors accounted for just under half of the variance of the MAFtrel. Interestingly,

Table 3 Multivariate analyses showing significant factors associated with the total malaria attributable fraction relative to the baseline haemoglobin in falciparum infected patients

\begin{tabular}{llll}
\hline Independent variable & Coefficient & $\mathbf{9 5 \% ~ C l s}$ & $\mathbf{P}$ \\
\hline Papuan ethnicity $^{*}$ & -6.41 & $-12.73--0.099$ & 0.047 \\
Day 0 haemoglobin $^{\dagger}$ & -3.37 & $-4.95--1.79$ & 0.000 \\
Day 0 splenomegaly $^{*}$ & 6.69 & $0.17-13.21$ & 0.045 \\
Illness duration $^{\S}$ & 0.71 & $0.073-1.34$ & 0.030 \\
Constant & 49.53 & $29.02-70.04$ & 0.000
\end{tabular}

No factors were identified in the vivax infected patients.

* dichotomous variable (present yes / no).

${ }^{+}$Continuous variable measured in $\mathrm{g} / \mathrm{dL}$.

$\S$ measured in days. ethnicity was not significant in the bivariate analysis and when excluded from the multivariate analysis, the model was less good. Given that the falciparum infected Papuans had similar Hb dynamics as the non-Papuans; these statistical findings regarding the Papuans should be interpreted cautiously.

Longer illness duration and splenomegaly are factors associated with a lower D0 $\mathrm{Hb}$ which in turn is a stimulus for increased erythropoietin production. Thus, with treatment, the bone marrow response may be more robust as the suppressing effects of cytokines and haemozoin on it are reduced and as spleen size reduces, so red cell survival increases [1,22-24]. Although the bone marrow response appears more robust in patents with a lower baseline $\mathrm{Hb}$, they did not "catch up" with the nonanaemic patients by study end. Furthermore, the D28 and D0 Hbs correlated positively (the latter explained $~ 25 \%$ of the D28 Hb variance). Therefore, "if you start low, you finish low", despite better MAFtrel values. Longer follow up would have given data on recovery times for the anaemic patients and may have shown, like Price et al. in Karen children and adults, that anaemic patient recover more slowly than those without anaemia [2]. Moderate anaemia $(<11 \mathrm{~g} / \mathrm{dL})$ was common $(\sim 23 \%)$ at presentation and is in broad agreement with $18 \%$ found in the Karen, using a haematocrit $<30 \%$ [2]. Factors associated with anaemia in the Karen were with age $<5$, splenomegaly, hepatomegaly, female sex, and prolonged illness, overlapping with some of the findings in the Papuan and non-Papuan adults.

The roles of ethnicity and NAI in the epidemiological context of NE Papuan are interesting questions. Data from this study suggest that the Papuans were haematologically disadvantaged when infected with $P$. vivax; they had persistently lower mean $\mathrm{Hb}$ concentrations post treatment compared to the non-Papuans. The indigenous Papuans had greater malaria exposure, because of their longer residence in Papua, suggesting that there may 
have been differences in NAI between the two groups. Data from this area show there is divergence in the acquisition of NAI for the two main malaria species. NAI to $P$. falciparum develops after approximately two years of intense transmission in newly arriving non-Papuans [32,33]. The median residence time for non-Papuans in this study was 3 years; thus, half or more of them probably had similar degrees of NAI to $P$. falciparum as the Papuans. Similar degrees of NAI against $P$. falciparum probably explain the similar baseline parasitaemia and mean $\mathrm{Hb}$ concentrations from baseline to D28 despite the initial fall in mean $\mathrm{Hb}$ for the non-Papuans. By contrast, NAI to P. vivax takes longer to acquire and NAI was higher in the Papuans as evidenced by their significantly lower median, baseline vivax parasitaemia; however, their vivax related NAI was not haematologically beneficial.

The Papuan haematological conundrum is unexplained and might represent host factors like G6PD deficiency, ovalocytosis, HIV, iron deficiency or pathophysiological factor/s unique to the Papuans that operate more in $P$. vivax infections, e.g. greater red cell fragility/splenic destruction, more cytokine induced bone marrow suppression, slower bone marrow recovery. These speculations underscore the lack of knowledge of the mechanisms of $\mathrm{Hb}$ dynamics in these two populations and call for further detailed investigation [39].

This study has several limitations. The analyses were supplementary to those of a small clinical trial of 162 adult patients and follow up was 28 days, two weeks before $\mathrm{Hb}$ stabilizes. By contrast, Price et al. analysed $\sim 1,500$ adults and children over 63 days [2]. The study herein reported was not designed a priori to detail the haematological responses; thus, key haematological parameters like the mean corpuscular volume, reticulocyte counts, iron metabolic parameters, G6PD status, presence of thalassaemia and ovalocytosis were not tested. Such data would be essential in a haematological investigation in ethnically diverse NE Papua.

To conclude, this study has shown similar Hb dynamics between vivax and falciparum malaria but un explained differences between vivax-infected Papuans and nonPapuans.

\section{Additional files}

Additional file 1: The relationship between the absolute change in the initial fall (hbdiff30) in haemoglobin on Day 3 and the baseline haemoglobin concentration (hb0) in $\mathrm{g} / \mathrm{dL}$ for the Papuans and non-Papuans combined.

Additional file 2: Box plots of haemoglobin dynamics as a function of treatment arms in all patients with both species. $C=$ chloroquine alone, $C D=$ chloroquine plus doxycycline, Dox = doxycycline alone.

\section{Competing interest}

None of the authors have a conflict of interest.

\section{Authors' contributions}

CO conceived the original design. CO, WRJT, ET, SLH, TLR developed the protocol. WRJT, HW, HB, Taufik, ET, SB executed the study. WRJT analysed the data and wrote the first draft of the paper. TLR, SLH, CO, ET contributed significantly to revisions of the paper. All authors read and approved the final manuscript.

\section{Acknowledgments}

We are grateful to the patients for joining this study. The authors wish to thank the following for their contribution to the study: (i) the nurses at the Jayapura General Hospital and the Indonesian Naval Hospital (ii) Drs. Oyong (Jayapura General Hospital) and Kristanto (Indonesian Naval Hospital) for their support in study execution, (iii) Nona Nurjaya Kadir and Pak Ferryanto C. Sanggamelefor slide reading, laboratory work, and data management, (iv) Pak Purnomo Prodjodipuro, Sofyan Masbar, Awalludin Sutamiharja and Pak Suradi for slide reading (v) Dr. Budi Subianto, (Provincial Health Office, Jayapura) for facilitating study execution, (vi) Dr. Kasia Stepniewska for helpingWRJT with some of the statistics. CO, SLH and TLR were active duty United States military personnel at the time they contributed to this work; HW and HB were Foreign Service nationals working for the US Government; and WRJT was an Intergovernmental Personnel Act employee working for the US Government. The work of these individuals was prepared as part of official government duties. Title 17 U.S.C. \$101 defines a U.S. Government work as a work prepared by a military service member or employee of the U.S. Government as part of that person's official duties. Title 17 U.S.C. \$105 provides that 'Copyright protection under this title is not available for any work of the United States Government.' The work of authors affiliated with the US Naval Medical Research Unit \#2 was supported by work unit number DoD 63002A M00101 HEX 2406. The study protocol for the clinical research presented in this manuscript was approved by the NAMRU-2 and Indonesian Ministry of Health Institutional Review Boards, in compliance with all applicable Federal regulations governing protection of human subjects. All study subjects gave written informed consent. The views expressed in this article are those of the authors and do not necessarily reflect the official policy or position of the Indonesian Military, the Indonesian Ministry of Health, the US Department of the Navy, the US Department of the Army, the US Department of Defense, or the U.S. Government.

\section{Funding}

This study was funded by the US Naval Medical Research and Development Command (DoD 63002A M00101 HEX 2406).

\section{Disclaimer}

The views expressed in this paper are the authors' and do not in any way represent those of the Indonesian Navy, the Indonesian Ministry of Health, or the US Navy.

\section{Author details}

'The US Navy Medical Research Unit no. 2 (NAMRU-2), Jakarta, Indonesia. ${ }^{2}$ Department of Tropical Medicine, Tulane University School of Public Health New Orleans, USA. ${ }^{3}$ Centre for Health Research and Development, National Institutes of Health, Jakarta, Indonesia. ${ }^{4}$ Armed Forces Research Institute of Medical Science, Bangkok, Thailand. ${ }^{5}$ Indonesian Naval Hospital, Jayapura, Papua, Indonesia. ${ }^{6}$ Rumah Sakit Umum, Jayapura, Papua, Indonesia. ${ }^{7}$ Naval Medical Research Center, Bethesda, MD, USA.

Received: 4 January 2013 Accepted: 5 June 2013

Published: 19 June 2013

\section{References}

1. Wickramasinghe SN, Abdalla SH: Blood and bone marrow changes in malaria. Baillieres Best Pract Res Clin Haematol 2000, 13:277-299.

2. Price RN, Simpson JA, Nosten F, Luxemburger C, Hkirjaroen L, ter Kuile F, Chongsuphajaisiddhi T, White NJ: Factors contributing to anemia after uncomplicated falciparum malaria. Am J Trop Med Hyg 2001, 65:614-622.

3. Bruneel F, Gachot B, Wolff M, Regnier B, Danis M, Vachon F: Resurgence of blackwater fever in long-term European expatriates in Africa: report of 21 cases and review. Clin Infect Dis 2001, 32:1133-1140.

4. van Eijk AM, Ayisi JG, Ter erKuile FO, Misore AO, Otieno JA, Kolczak MS, Kager PA, Steketee RW, Nahlen BL: Malaria and human immunodeficiency 
virus infection as risk factors for anemia in infants in Kisumu, western Kenya. Am J Trop Med Hyg 2002, 67:44-53.

5. Dreyfuss ML, Stoltzfus RJ, Shrestha JB, Pradhan EK, LeClerq SC, Khatry SK, Shrestha SR, Katz J, Albonico M, West KP Jr: Hookworms, malaria and vitamin A deficiency contribute to anemia and iron deficiency among pregnant women in the plains of Nepal. J Nutr 2000, 130:2527-2536.

6. Looareesuwan S, Davis TM, Pukrittayakamee S, Supanaranond W, Desakorn V, Silamut K, Krishna S, Boonamrung S, White NJ: Erythrocyte survival in severe falciparum malaria. Acta Trop 1991, 48:263-270

7. Anstey NM, Russell B, Yeo TW, Price RN: The pathophysiology of vivax malaria. Trends Parasitol 2009, 25:220-227.

8. Hue NT, Charlieu JP, Chau TT, Day N, Farrar JJ, Hien TT, Dunstan SJ: Glucose-6-phosphate dehydrogenase (G6PD) mutations and haemoglobinuria syndrome in the Vietnamese population. Malar J 2009, 8:152.

9. Luzzatto L: The rise and fall of the antimalarial Lapdap: a lesson in pharmacogenetics. Lancet 2010, 376:739-741.

10. Collins WE, Jeffery GM, Roberts JM: A retrospective examination of anemia during infection of humans with Plasmodium vivax. Am J Trop Med Hyg 2003, 68:410-412.

11. Jakeman GN, Saul A, Hogarth WL, Collins WE: Anaemia of acute malaria infections in non-immune patients primarily results from destruction of uninfected erythrocytes. Parasitology 1999, 119(Pt 2):127-133.

12. Looareesuwan $S$, Ho M, Wattanagoon $Y$, White NJ, Warrell DA, Bunnag D, Harinasuta T, Wyler DJ: Dynamic alteration in splenic function during acute falciparum malaria. N Engl J Med 1987, 317:675-679.

13. Anyona SB, Schrier SL, Gichuki CW, Waitumbi JN: Pitting of malaria parasites and spherocyte formation. Malar J 2006, 5:64.

14. Lamikanra AA, Brown D, Potocnik A, Casals-Pascual C, Langhorne J, Roberts DJ: Malarial anemia: of mice and men. Blood 2007, 110:18-28.

15. Dondorp AM, Nyanoti M, Kager PA, Mithwani S, Vreeken J, Marsh K: The role of reduced red cell deformability in the pathogenesis of severe falciparum malaria and its restoration by blood transfusion. Trans $R$ SoC Trop Med Hyg 2002, 96:282-286.

16. Dondorp AM, Angus BJ, Chotivanich K, Silamut K, Ruangveerayuth R, Hardeman MR, Kager PA, Vreeken J, White NJ: Red blood cell deformability as a predictor of anemia in severe falciparum malaria. Am J Trop Med Hyg 1999, 60:733-737.

17. Handayani S, Chiu DT, Tjitra E, Kuo JS, Lampah D, Kenangalem E, Renia L, Snounou G, Price RN, Anstey NM, Russell B: High deformability of Plasmodium vivax-infected red blood cells under micro fluidic conditions. J Infect Dis 2009, 199:445-450.

18. Angus BJ, Chotivanich $K$, Udomsangpetch $R$, White $N J$ : In vivo removal of malaria parasites from red blood cells without their destruction in acute falciparum malaria. Blood 1997, 90:2037-2040.

19. Newton PN, Chotivanich $K$, Chierakul W, Ruangveerayuth $R$, Teerapong $P$, Silamut $\mathrm{K}$, Looareesuwan S, White NJ: A comparison of the in vivo kinetics of Plasmodium falciparum ring-infected erythrocyte surface antigenpositive and -negative erythrocytes. Blood 2001, 98:450-457.

20. Phillips RE, Looareesuwan S, Warrell DA, Lee SH, Karbwang J, Warrell MJ, White NJ, Swasdichai C, Weatherall DJ: The importance of anaemia in cerebral and uncomplicated falciparum malaria: role of complications, dyserythropoiesis and iron sequestration. Q J Med 1986, 58:305-323.

21. Clark IA, Chaudhri G: Tumour necrosis factor may contribute to the anaemia of malaria by causing dyserythropoiesis and erythro phagocytosis. Br J Haematol 1988, 70:99-103.

22. Othoro C, Lal AA, Nahlen B, Koech D, Orago AS, Udhayakumar V: A low interleukin-10 tumor necrosis factor-alpha ratio is associated with malaria anemia in children residing in a holoendemic malaria region in western Kenya. J Infect Dis 1999, 179:279-282.

23. Casals-Pascual C, Kai O, Cheung JO, Williams S, Lowe B, Nyanoti M, Williams TN, Maitland K, Molyneux M, Newton CR, Peshu N, Watt SM, Roberts DJ: Suppression of erythropoiesis in malarial anemia is associated with hemozoin in vitro and in vivo. Blood 2006, 108:2569-2577.

24. Kurtzhals JA, Rodrigues O, Addae M, Commey JO, Nkrumah FK, Hviid L: Reversible suppression of bone marrow response to erythropoietin in Plasmodium falciparum malaria. Br J Haematol 1997, 97:169-174.

25. Burgmann H, Looareesuwan S, Kapiotis S, Viravan C, Vanijanonta S, Hollenstein U, Wiesinger E, Presterl E, Winkler S, Graninger W: Serum levels of erythropoietin in acute Plasmodium falciparum malaria. Am J Trop Med Hyg 1996, 54:280-283.
26. Nussenblatt V, Mukasa G, Metzger A, Ndeezi G, Garrett E, Semba RD: Anemia and interleukin-10, tumor necrosis factor alpha, and erythropoietin levels among children with acute, uncomplicated Plasmodium falciparum malaria. Clin Diagn Lab Immunol 2001, 8:1164-1170.

27. Camacho LH, Gordeuk VR, Wilairatana P, Pootrakul P, Brittenham GM Looareesuwan S: The course of anaemia after the treatment of acute, falciparum malaria. Ann Trop Med Parasitol 1998, 92:525-537.

28. Mayxay M, Khanthavong M, Lindegardh N, Keola S, Barends M, Pongvongsa T, Yapom R, Annerberg A, Phompida S, Phetsouvanh R, White NJ, Newton PN: Randomized comparison of chloroquine plus sulfadoxinepyrimethamine versus artesunate plus mefloquine versus artemetherlumefantrine in the treatment of uncomplicated falciparum malaria in the Lao People's Democratic Republic. Clin Infect Dis 2004, 39:1139-1147.

29. Srichaikul T, Panikbutr N, Jeumtrakul P: Bone-marrow changes in human malaria. Ann Trop Med Parasitol 1967, 61:40-51.

30. Premji Z, Hamisi Y, Shiff C, Minjas J, Lubega P, Makwaya C: Anaemia and Plasmodium falciparum infections among young children in an holoendemic area, Bagamoyo, Tanzania. Acta Trop 1995, 59:55-64.

31. Bloland PB, Boriga DA, Ruebush TK, McCormick JB, Roberts JM, Oloo AJ, Hawley W, Lal A, Nahlen B, Campbell CC: Longitudinal cohort study of the epidemiology of malaria infections in an area of intense malaria transmission II. Descriptive epidemiology of malaria infection and disease among children. Am J Trop Med Hyg 1999, 60:641-648.

32. Baird JK, Purnomo, Basri H, Bangs MJ, Andersen EM, Jones TR, Masbar S, Harjosuwarno S, Subianto B, Arbani PR: Age-specific prevalence of Plasmodium falciparum among six populations with limited histories of exposure to endemic malaria. Am J Trop Med Hyg 1993, 49:707-719.

33. Baird JK, Jones TR, Danudirgo EW, Annis BA, Bangs MJ, Basri H, Purnomo, Masbar S: Age-dependent acquired protection against Plasmodium falciparum in people having two years exposure to hyperendemic malaria. AmJTrop Med Hyg 1991, 45:65-76.

34. Taylor WR, Widjaja H, Richie TL, Basri H, Ohrt C, Tjitra, Taufik E, Jones TR, Kain KC, Hoffman SL: Chloroquine/doxycycline combination versus chloroquine alone, and doxycycline alone for the treatment of Plasmodium falciparum and Plasmodium vivax malaria in northeastern Irian Jaya, Indonesia. AmJTrop Med Hyg 2001, 64:223-228.

35. Taylor WR, Widjaja H, Basri H, Ohrt C, Taufik T, Tjitra E, Baso S, Fryauff D, Hoffman SL, Richie TL: Changes in the total leukocyte and platelet counts in Papuan and non Papuan adults from northeast Papua infected with acute Plasmodium vivax or uncomplicated Plasmodium falciparum malaria. Malar J 2008, 7:259.

36. Jones TR, Baird JK, Basri H, Purnomo, Danudirgo EW: Prevalence of malaria in native and transmigrant populations. Effects of age and history of exposure. Trop Geogr Med 1991, 43:1-6.

37. WHO: Iron deficiency anaemia: assessment, prevention and control: a guide for programme managers. Geneva: World Health Organization; 2001.

38. Poravuth $Y$, Socheat $D$, Rueangweerayut $R$, Uthaisin C, Pyae Phyo A, Valecha N, Rao BH, Tjitra E, Purnama A, Borghini-Fuhrer I, Duparc S, Shin CS, Fleckenstein L: Pyronaridine-artesunate versus chloroquine in patients with acute Plasmodium vivax malaria: a randomized, double-blind, non-inferiority trial. PLOS One 2011, 6:e14501.

39. Douglas NM, Anstey NM, Buffet PA, Poespoprodjo JR, Yeo TW, White NJ, Price RN: The anaemia of Plasmodium vivax malaria. Malar J 2012, 11:135.

doi:10.1186/1475-2875-12-209

Cite this article as: Taylor et al:: Haemoglobin dynamics in Papuan and non-Papuan adults in northeast Papua, Indonesia, with acute, uncomplicated vivax or falciparum malaria. Malaria Journal 2013 12:209. 